\title{
Novel insights into erythroid development revealed through in vitro differentiation of GATA-1 ${ }^{-}$embryonic stem cells
}

\author{
Mitchell J. Weiss, ${ }^{1}$ Gordon Keller, ${ }^{2}$ and Stuart H. Orkin ${ }^{1,3,4}$ \\ ${ }^{1}$ Division of Hematology-Oncology, Children's Hospital, Dana Farber Cancer Institute, Department of Pediatrics, Harvard \\ Medical School, Boston, Massachusetts 02115 USA; ${ }^{3}$ Howard Hughes Medical Institute, Boston, Massachusetts USA; ${ }^{2}$ The \\ National Jewish Center, Denver, Colorado 80206 USA.
}

\begin{abstract}
Mouse embryonic stem (ES) cells lacking the transcription factor GATA-1 do not produce mature red blood cells either in vivo or in vitro. To define the consequences of GATA-1 loss more precisely, we used an in vitro ES cell differentiation assay that permits enumeration of primitive $(E r y P)$ and definitive (EryD) erythroid

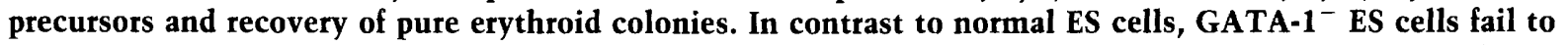
generate EryP precursors. EryD precursors, however, are normal in number but undergo developmental arrest and death at the proerythroblast stage. Contrary to initial expectations, arrested GATA-1 ${ }^{-}$-definitive proerythroblasts express GATA target genes at normal levels. Transcripts of the related factor GATA-2 are remarkably elevated in GATA-1 ${ }^{-}$proerythroblasts. These findings imply substantial interchangeability of GATA factors in vivo and suggest that GATA-1 normally serves to repress GATA-2 during erythropoiesis. The approach used here is a paradigm for the phenotypic analysis of targeted mutations affecting hematopoietic development.
\end{abstract}

[Key Words: Mouse; ES cells; erythroid development; transcription factor; in vitro differentiation]

Received February 10,1994; revised version accepted April 14, 1994.

Studies of globin gene regulation and red blood cell development have served as important models for defining mechanisms responsible for cell-specific expression and differentiation. Production of mature erythroid cells from pluripotent hematopoietic stem cells reflects two interrelated, overlapping processes. First, as stem cells give rise to multipotential progenitors and ultimately erythroid precursors, developmental potential becomes progressively restricted. Second, an erythroid program of transcription is established to express globins and other proteins characteristic of the mature red blood cell. Within the embryo, the site of hematopoiesis shifts during development from the yolk sac to the fetal liver (Brotherton et al. 1979; Wood 1982). Stem cells within the fetal liver originate either from the yolk sac or from an intraembryonic site near the dorsal aorta /Godin et al. 1993; Medvinsky et al. 1993). Erythroid cells developing in the yolk sac are termed primitive and synthesize predominantly embryonic globins, whereas those found in the fetal liver are definitive and express predominantly adult globins. A fruitful approach to elucidating these complex events relies on the identification of DNA-

${ }^{4}$ Corresponding author. binding proteins that direct erythroid-specific transcription. This is based on the premise that such regulators may also participate in early stages of erythropoiesis; therefore, the transcription factor GATA-1 has emerged as a central regulator for erythroid development (Orkin 1992).

GATA-1 is the founding member of a family of zinc finger proteins that recognize a GATA consensus motif (Evans and Felsenfeld 1989; Tsai et al. 1989). Potential target sites are found in the regulatory elements of virtually all erythroid-expressed genes (Evans et al. 1988), as well as in the core regions of the globin locus control regions (LCRs) (Grosveld et al. 1987; Orkin 1990; Philipsen et al. 1990; Talbot et al. 1990). The GATA family proteins exhibit complex patterns of expression /Yamamoto et al. 1990). Within hematopoietic cells, expression of GATA-1 and two related proteins, GATA-2 and GATA-3, overlaps in some lineages and at some developmental stages. Populations enriched in multipotential progenitors express GATA-2 at high level, and GATA-1 (and possibly GATA-3) at a much lower level (Sposi et al. 1992; Leonard et al. 1993). GATA-1 and GATA-2 are coexpressed at high levels in mast and megakaryocytic cells (Martin et al. 1990; Romeo et al. 1990), whereas GATA-3 is abundant in T-lymphoid cells /Yamamoto et 
al. 1990; Ho et al. 1991; Joulin et al. 1991; Ko et al. 1991). Maturing mammalian erythroid cells contain abundant GATA-1 but little (if any) GATA-2 or GATA-3 (Zon et al. 1991a; Leonard et al. 1993).

Despite overlapping expression of these factors, GATA-1 is essential for normal erythroid development, as revealed by gene targeting (Smithies et al. 1985; Capecchi 1989) in mouse embryo-derived stem (ES) cells (Pevny et al. 1991). Male ES cells in which the X-linked GATA-l gene is disrupted do not contribute to the mature erythroid compartment in chimeric mice, although they contribute to the white cell fraction of blood and to all nonhematopoietic tissues tested. Accordingly, no mature erythroid cells are produced by GATA-1 ${ }^{-}$ES cells with in vitro embryoid body (EB; see below) differentiation (Simon et al. 1992), and embryonic and adult globin RNAs are virtually undetectable. Reintroduction of a normal GATA-1 transgene into the mutant ES cells rescues erythroid development both in vivo and in vitro (Simon et al. 1992). Hence, the phenotype of the GATA$1^{-}$ES cells is solely attributable to the loss of GATA-1 function.

Although prior studies demonstrate a requirement for GATA-1, they do not resolve several important questions. Specifically, we wish to answer the following: At what stage is erythroid differentiation blocked in the absence of GATA-1? Are GATA-1- primitive and definitive erythroid precursors affected to the same extent? How severely does the ablation of GATA-l affect the expression of presumptive GATA-1 target genes? Is there cross regulation or compensation by other GATA-factors?

To address these issues and explore a general approach to the phenotypic analysis of loss-of-function mutations affecting hematopoiesis, we examined the in vitro developmental potential of GATA-1 - ES cells. Upon differentiation in vitro, totipotent ES cells develop into aggregates, termed EBs, which contain various committed cell types including hematopoietic precursors (Doetschman et al. 1985; Burkert et al. 1991; Schmitt et al. 1991; Wiles and Keller 1991; Keller et al. 1993). Hematopoiesis can be observed directly in EBs. Alternatively, hematopoietic precursors are enumerated in colony assays by disaggregation of differentiating EBs and subsequent replating into methylcellulose cultures (Schmitt et al. 1991; Keller et al. 1993). This two-step assay has at least three advantages. First, precursors responsive to different hematopoietic growth factors are scored in a fashion analogous to traditional hematopoietic colony assays. Second, the temporal appearance of precursors from normal ES cells in developing EBs resembles that in the early embryo. Primitive erythroid (EryP) precursors, dependent on erythropoietin (Epo), are most abundant in 6- to 7-day EBs, whereas definitive precursors (EryD), dependent on Epo and kit-ligand (KL, or stem cell factor) for their growth, persist in 10- to 14-day EBs. Macrophage and granulocyte precursors are abundant in 6- to 14-day EBs. Third, hematopoietic colonies, devoid of ES cells or other differentiated cell types arising in EBs, may be recovered for morphologic and molecular analyses.
Here, we describe novel insights into the consequences of GATA-1 loss accessed through the two-step in vitro assay. Specifically, we have distinguished different effects of GATA-1 loss on primitive and definitive erythropoiesis, shown that definitive erythroid cells undergo a developmental arrest followed by premature death, and defined the profile of RNA transcripts in the blocked cells. Contrary to our expectations, GATA target genes, including globins, are expressed at near normal levels in these cells. GATA-2 expression, however, is remarkably increased. These findings provide the first evidence for cross regulation of GATA proteins and sug. gest that GATA-2 can compensate partially for GATA-1 until the late stage of erythroid development. The approach we developed serves as a paradigm for studies of the consequences of other targeted gene mutations on hematopoiesis.

\section{Results}

In the experiments described below we examined hematopoietic development of two independent GATA-1 ${ }^{-}$ ES clones (Pevny et al. 1991) in the two-step in vitro differentiation assay (Keller et al. 1993). RNA transcript analysis of pooled erythroid colonies was performed by semiquantitative reverse-transcriptase-polymerase chain reaction (RT-PCR) (Saiki et al. 1985; Ferre et al. 1992; see Materials and methods). All results discussed were comparable between these clones; hence, they relate to consequences of GATA-1 loss, rather than to clonal variation.

\section{GATA-1- ES cells exhibit a complete block to primitive erythropoiesis}

The EryP precursors were scored by replating cells derived from EBs of wild-type and GATA-1 - ES cells into methylcellulose containing Epo (Keller et al. 1993). As shown in Figure 1A, EBs of wild-type origin generate EryP precursors that are most abundant at 6 days and disappear by 14 days. Wild-type EryP colonies exhibit tight morphology and strong hemoglobinization (Fig. 1B). In contrast, EBs derived from the GATA-1 ${ }^{-}$ES cells contain no detectable EryP precursors at any time (Fig. $1 \mathrm{~A}, \mathrm{~B})$. Of particular note, no abortive EryP colonies are evident in cultures of the mutant ES cells. These findings support a requirement for GATA-l at the earliest stage of primitive erythropoiesis definable by current methods.

\section{GATA-1- EryD precursors are arrested at the proerythoblast stage and die}

The EryD precursors were enumerated by replating EBs in the presence of Epo and KL (Keller et al. 1993). The EryD precursors, scored 4-5 days after replating, are present at similar frequencies in EBs derived from wildtype or mutant ES cells (Fig. 2A). Development of these colonies is dependent on the presence of both Epo and $\mathrm{KL}$. Few develop in $\mathrm{KL}$ alone (data not shown). The re- 
A

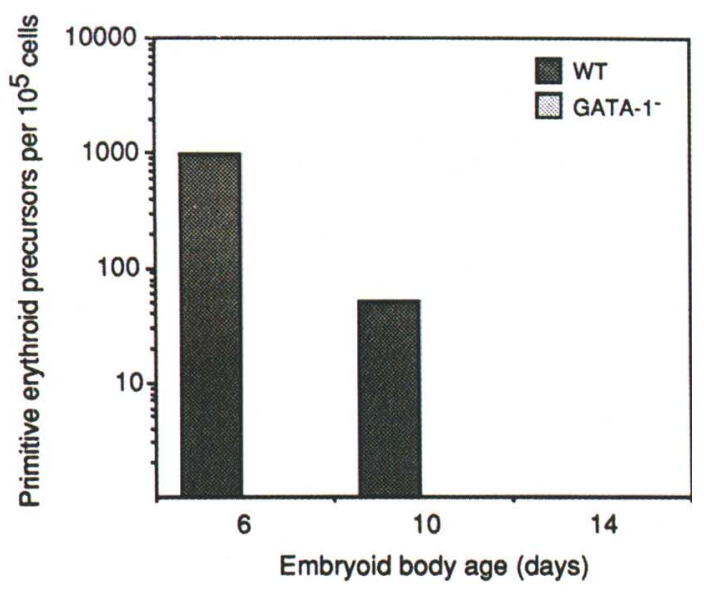

B

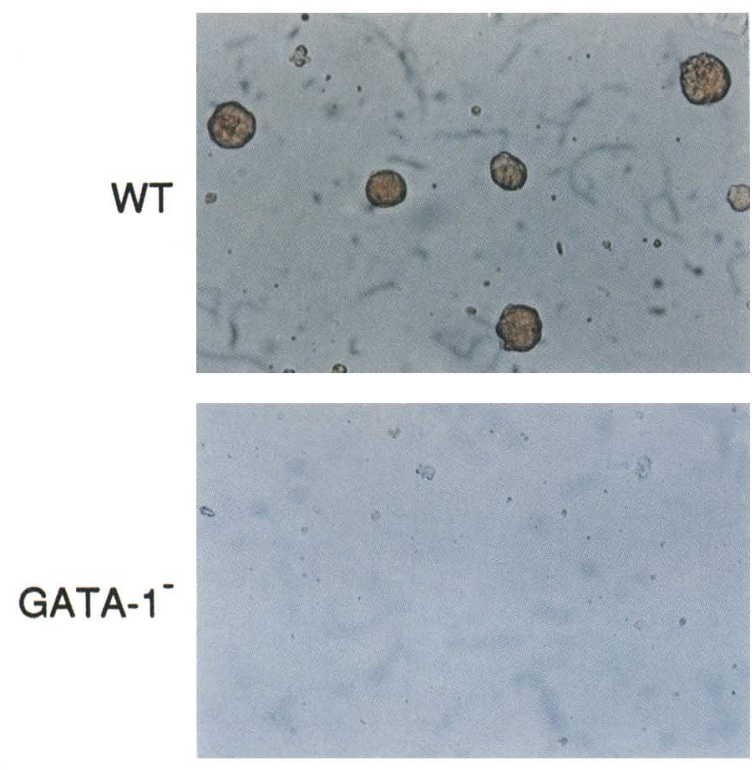

Figure 1. Primitive erythropoiesis is blocked in GATA-1 - ES cells. $(A)$ EryP precursors were enumerated following secondary plating of wild-type (WT) and GATA-1 $1^{-}$cells into methylcellulose media containing Epo. Embryoid bodies were disaggregated at 6,10, and 14 days. Note the absence of GATA-1- EryP precursors at all times. $(B)$ Typical EryP colonies derived from 6-day-old wild-type embryoid bodies. No EryP colonies were observed after replating of GATA- $1^{-}$embryoid bodies. Original magnification, $400 \times$.

quirement for Epo suggests that a functional erythropoietin receptor (EpoR) is produced by GATA-1 ${ }^{-}$cells, a finding substantiated by RNA analysis (see below).

Because GATA- $1^{-}$ES cells do not contribute to mature, definitive erythroid cells in vivo (Pevny et al. 1991), the appearance of mutant erythroid colonies implies either a difference in the behavior of these cells in vivo and in vitro or an arrest during their maturation. Cells within the GATA-1- ${ }^{-}$ES-derived colonies are develop- mentally arrested and die. Three to four days after replating, developing wild-type and mutant erythroid colonies are similar in appearance (Fig. 2B); cytologic smears show that they consist predominantly of proerythroblasts (Fig. 3A,B). In some colonies the cells acquire a pink hue, indicative of the onset of hemoglobinization. GATA-1 ${ }^{-}$proerythroblasts initially appear healthy but are somewhat larger in size than wild-type cells (Fig. $3 \mathrm{~A}, \mathrm{~B})$. Between days 4 and 6 , cells within wild-type colonies mature, become visibly hemoglobinized (Fig. 2B), and acquire morphology characteristic of late normoblasts (Fig. 3C,E). In contrast, cells within GATA- ${ }^{-}$colonies fail to hemoglobinize appreciably (Fig. 2B). Cytology of mutant colonies reveals maturation arrest with dead and dysplastic cells evident by day 5 of colony development (Fig. 3D). Staining with vital dye reveals a precipitous fall in cell viability within the mutant colonies between days 4 and 6 after replating (Fig. 3F). Thus, GATA-1 - EryD precursors are intrinsically abnormal, as reflected by a developmental arrest and premature death at a relatively late stage in their maturation. With respect to their initial appearance, growth factor requirements, and persistence in EBs beyond 6 days, GATA-1 ${ }^{-}$ EryD precursors are otherwise indistinguishable from wild type cells.

\section{GATA-1-1 -derived myeloid cells appear normal}

Replating experiments were performed to assess the consequences of GATA-1 loss on other hematopoietic lineages. Macrophage precursor development in GATA-1 ${ }^{-}$ EBs exhibits normal kinetics (Fig. 4). Macrophages derived from these colonies are normal in morphology, and do not display a shortened survival in vitro (not shown). In addition, granulocyte-macrophage and mixed colonies containing normal-appearing neutrophils were observed at approximately equal frequencies in replatings of wild-type and mutant ES cells. Thus, GATA-1 is not required for myeloid development.

\section{Nonglobin GATA target genes are transcribed in GATA-1- proerythroblasts}

The presence of developmentally arrested definitive erythroid precursors after replating of EBs derived from mutant ES cells affords a unique opportunity to assess the status of presumptive GATA target genes in the deficient cells. Among nonglobin erythroid-expressed genes, the EpoR (D'Andrea et al. 1989), basic helix-loop-helix (bHLH) stem cell leukemia (SCL or tal-1) transcription factor (Begley et al. 1989, 1991), and erythroid Krüppellike transcription factor (EKLF) (Miller and Bieker 1993) genes are of special interest. In each, a GATA site situated in the proximal promoter is required for full promoter activity in erythroid cells and mediates trans-activation by forced GATA-1 expression in fibroblasts (Zon et al. 1991a; Aplan et al. 1992; M. Crossley and S.H. Orkin, unpubl.). Previously, it was speculated that loss of EpoR expression in GATA-1 ${ }^{-}$cells might account for their failure to develop normally, as starvation for sig- 


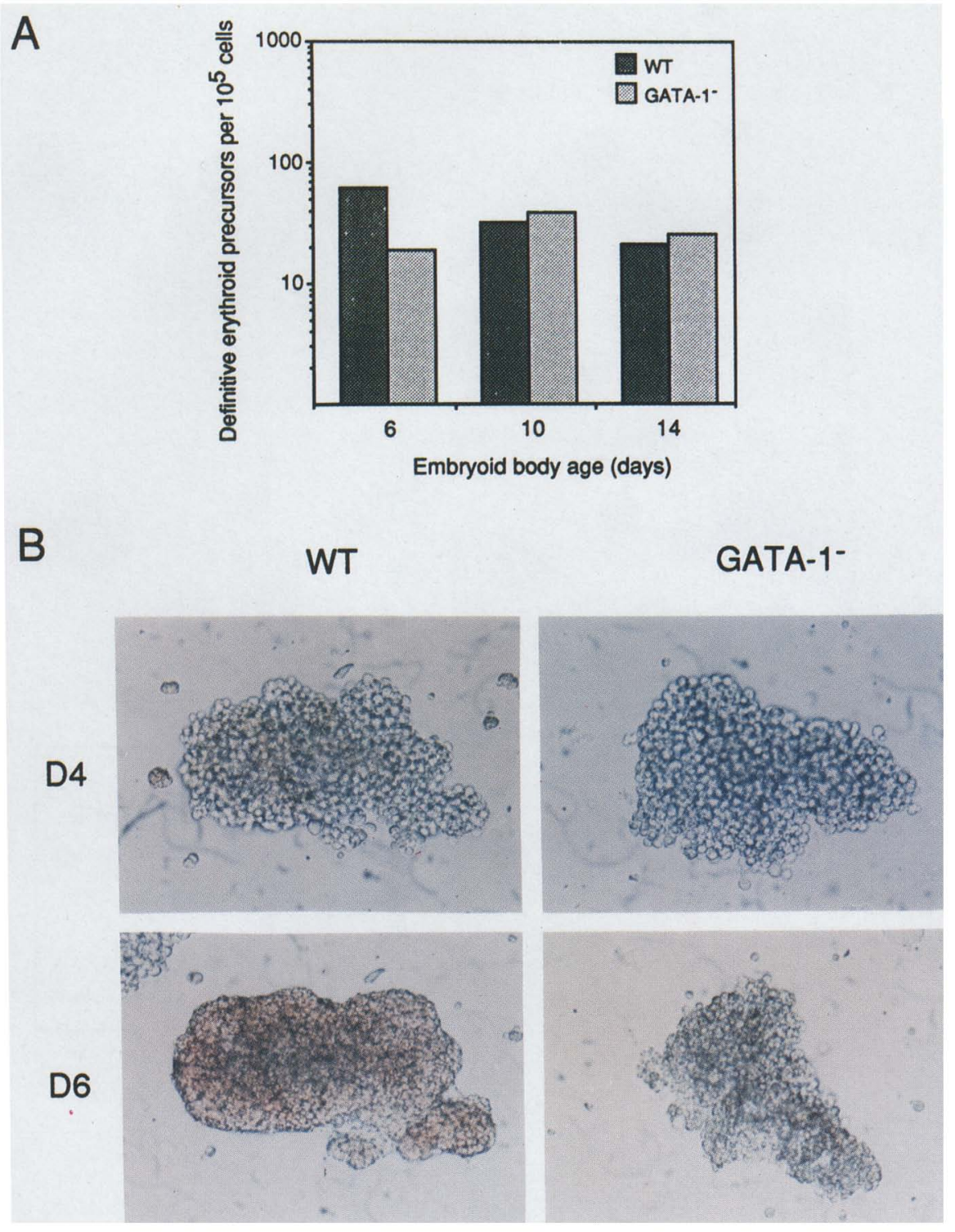

Figure 2. EryD precursors in GATA-1 embryoid bodies are blocked in the final stages of development. (A) EryD precursors were enumerated in GATA-1 ${ }^{-}$and wild-type (WT) embryoid bodies 6,10 , and 14 days old. GATA-1- precursors are present at normal frequencies and form colonies that are initially normal in appearance but fail to mature (see below). (B) Wild-type and GATA-1 - erythroid colony morphologies. Four-day-old wild-type and GATA-1 - erythroid colonies derived from 6-day-old embryoid bodies replated into Epo/KL are similar in appearance (top). By 6 days colony age (bottom), the wild-type EryD colony acquires a red color reflecting hemoglobin accumulation in maturing erythroid cells. In contrast, the agematched GATA- $1^{-}$colony fails to turn red and contains mainly dead cells. Original magnification, $200 \times$. naling through the EpoR would lead to apoptosis. The Epo responsiveness of the mutant colonies and the RNA data presented below exclude this simple model.

Wild-type and GATA- $1^{-}$EryD colonies were aspirated from methylcellulose cultures 3 days after replating of EB cells, pooled into mixes containing $\sim 50$ colonies of either type, and analyzed by semiquantitative RT-PCR for respective RNA transcripts /see Materials and methods). All cells were viable as determined by eosin exclusion.

Expression of EpoR, SCL, and EKLF transcripts in wild-type and GATA-1 ${ }^{-}$proerythroblasts is presented in Figure 5. Contrary to our initial expectations, approximately normal levels of EpoR and SCL transcripts [relative to hypoxanthine-guanine phosphoribosyl transferase (HPRT)] are present in the GATA-1 ${ }^{-}$proerythroblasts. Transcripts for EKLF are only modestly reduced $(20-60 \%$ of normal). Therefore, despite disruption of the
GATA-1 gene, several presumptive GATA factor-dependent target genes are expressed at near normal levels.

\section{Embryonic and adult globin genes are also expressed in GATA-1- proerythroblasts}

Considerable evidence indicates that G IA-1 participates directly in transcriptional regulation of globin genes in vertebrates. First, GATA sites are functionally important in globin gene promoters in several species (Evans et al. 1988; Knezetic and Felsenfeld 1989; Martin et al. 1989; Plumb et al. 1989; Watt et al. 1990; Evans and Felsenfeld 1991; Fong and Emerson 1992). Second, multiple GATA motifs are present in the core regions of both the $\alpha$ - and $\beta$-globin gene cluster LCRs (Higgs et al. 1990; Philipsen et al. 1990; Jarman et al. 1991; Talbot and Grosveld 1991) and comprise part of the minimal sequences required for their position-independent activ- 
Weiss et al.

Figure 3. Maturation arrest and premature cell death in GATA-1 - EryD cells. (AE) EryD cells from wild-type (WT) and GATA-1 ${ }^{-}$erythroid colonies stained with May-Grunwald/Giemsa. Four-day-old wildtype $(A)$ and mutant $(B)$ colonies contain predominantly normal-appearing proerythroblasts; consistently, the mutant cells appear slightly larger. At 5 days colony age, wild-type cells $(C)$ continue to mature, accumulate hemoglobin, and exhibit nuclear condensation. Cells from age-matched GATA-1 - colonies $(D)$ contain mainly dysplastic proerythroblasts and dead cells. By 6 days after replating, wild-type colonies (E) contain late normoblasts and erythrocytes, whereas GATA-1 ${ }^{-}$colonies contain mostly dead cells (not shown). Magnification, $320 \times .(F)$ Cell viability, as determined by eosin exclusion in groups of pooled colonies, drops sharply in GATA-1 ${ }^{-}$erythroid cells between days 4 and 6 of colony development.
WT

D4
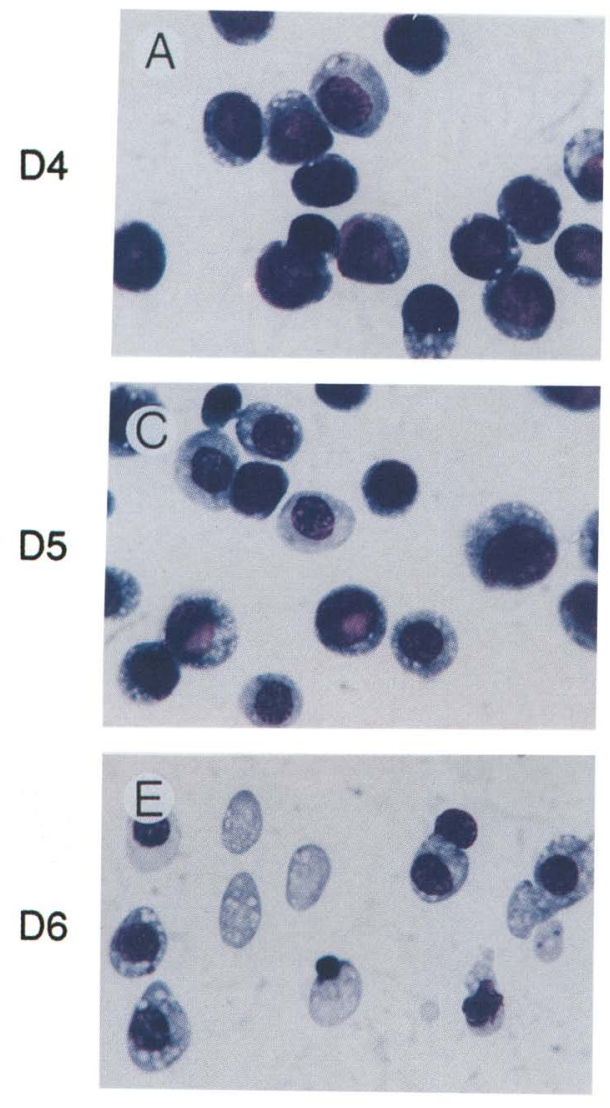
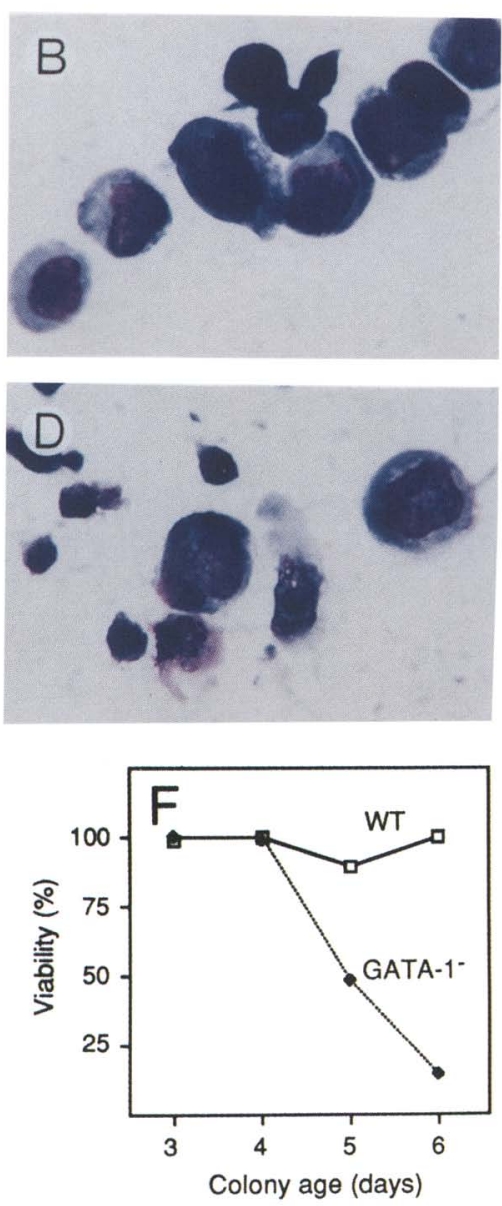

ity (Ellis et al. 1993; Philipsen et al. 1993). To assess the transcriptional status of globin genes in developing erythroid cells we harvested wild-type and GATA-1 ${ }^{-}$erythroid colonies and quantitated mRNAs by RT-PCR. Again, contrary to our initial expectations, embryonic $[\zeta$, $\beta \mathrm{Hl}, \epsilon$, and $\alpha$ (Leder et al. 1992)] and adult $(\alpha$ and $\beta$ ) globin transcripts are expressed at roughly normal levels in the GATA-1 ${ }^{-}$developmentally arrested precursors (Fig. 6; Table 1). Upon closer inspection of the relative levels in cells harvested on days 3,4 , and 5 after replating, additional trends are evident. In wild-type colonies, cellular maturation is associated with a progressive increase in $\beta$-major, the adult $\beta$-like chain. In arrested GATA-1 - erythroblasts, $\beta \mathrm{H} 1$ remains higher than in wild-type cells, whereas the level of $\beta$-major transcripts remains low throughout. These data suggest a relative shift in the expression of genes of the $\beta$-globin cluster from $\beta$-major to $\beta \mathrm{H} 1$ globin in the GATA-1 ${ }^{-}$cells.

Our detection of globin RNA expression in isolated ES-derived hematopoietic colonies in these experiments, as compared with our finding that globin RNAs are virtually absent in GATA-1 ${ }^{-}$EBs differentiated in vitro $/ \mathrm{Si}$ - mon et al. 1992) is not merely a reflection of the different sensitivities of RT-PCR and RNase protection methods. We compared RT-PCR and RNase protection assays directly on EB RNAs of wild-type and GATA-1 ${ }^{-}$origins, and confirmed our previous findings and the accuracy of RT-PCR quantitation (not shown). As discussed below, we believe that GATA-1 ${ }^{-}$precursors die rapidly within the context of late EBs.

\section{$c$-myb expression is increased in GATA-1- EryD cells}

The nuclear protooncogene $c-m y b$ is necessary for normal definitive erythropoiesis in the mouse (Mucenski et al. 1991). c-myb mRNA is relatively abundant in erythroid precursors, and levels decrease during terminal maturation (Lüscher and Eisenman 1990). Indirect evidence suggests that c-myb functions to promote precursor proliferation and that its down-regulation is necessary to enable the final stages of erythroid maturation (Clarke et al. 1988; Gewirtz and Calabrotta 1988; Todokoro et al. 1988; McClinton et al. 1990). To assess whether altered c-myb expression ensues after loss of 


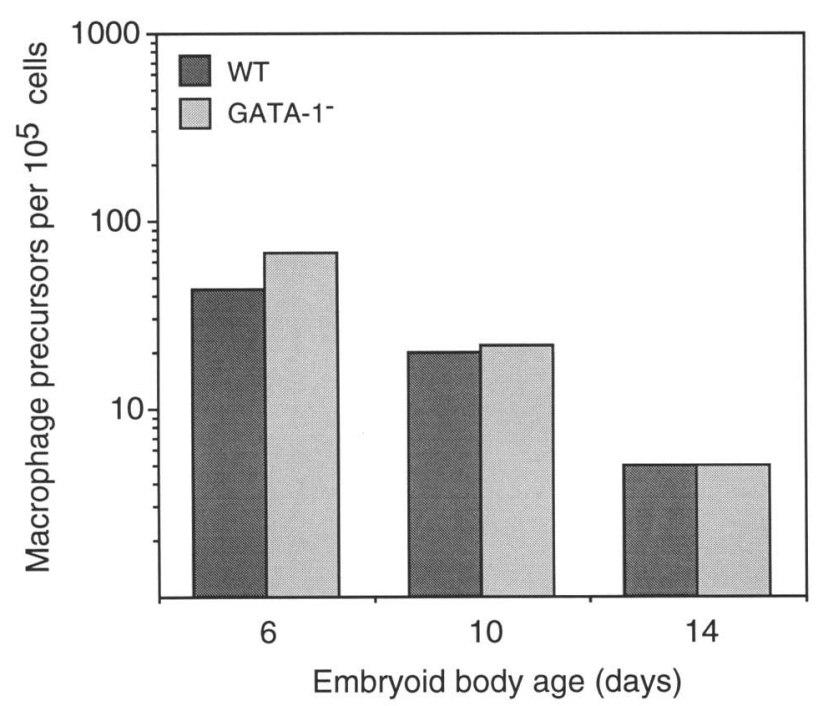

Figure 4. Macrophage precursor frequencies are similar in wild-type and GATA-1 ${ }^{-}$embryoid bodies at 6,10 , and 14 days. Macrophage precursors were scored 6-8 days after replating embryoid bodies into methylcellulose cultures containing IL-1, IL3 , granulocyte colony-stimulating, granulocyte-macrophage colony-stimulating factor, Epo, and $\mathrm{KL}$. Colonies containing $<20$ cells were not scored.

GATA-1, we quantitated c-myb RNA in day 3,4 , and 5 wild-type and mutant erythroid colonies (Fig. 7). Wildtype colonies express a low level of c-myb RNA, which declines slightly as cellular maturation proceeds. In contrast, GATA-1 ${ }^{-}$erythroid cells overexpress c-myb. By 5 days colony age, c-myb mRNA is eightfold greater relative to wild-type colonies.

\section{GATA-2 expression is dramatically up-regulated in GATA-1 ${ }^{-}$, EryD cells}

The expression of presumptive GATA target genes, in cluding all globins, in developmentally arrested GATA$1^{-}$ES cells presents a paradox consistent with two interpretations. On the one hand, the presumptive GATA targets may not be truly regulated through GATA factors in vivo. Alternatively, in the absence of GATA-1, another GATA factor might substitute in transcription of these target genes. To address these possibilities we quantitated RNA transcripts encoding two other members of the GATA family of transcription factors (Yamamoto et al. 1990), GATA-2 (Wilson et al. 1990; Dorfman et al. 1992) and GATA-3 (Yamamoto et al. 1990; Ho et al. 1991; Joulin et la. 1991; Ko et al. 1991), which are normally expressed in a subset of hematopoietic lineages. As shown in Figure 8, A and B, GATA-2 transcripts are dramatically elevated (40- to 68-fold) in developmentally arrested GATA-1 ${ }^{-}$cells assayed in day 3,4 , and 5 colonies. In contrast, GATA-3 transcripts are low and approximately equal in wild-type and mutant proerythroblasts (Fig. $8 \mathrm{C}$ ). Thus, GATA-2 expression is se- lectively up-regulated to a remarkable extent at all times of colony development in the absence of GATA-1.

\section{Discussion}

Targeted mutagenesis in mouse ES cells forms the basis of a genetic strategy for defining the roles of specific genes in mammalian development (Capecchi 1989). Study of phenotypes evident in homozygous mice generated by germ-line transmission and breeding has served as the predominant method of analysis. For genes important in hematopoiesis, examination of the contribution of mutant ES cells to blood cell lineages in chimeras (Pevny et al. 1991) and the in vitro developmental potential of ES cells (Simon et al. 1992) is particularly useful, especially in instances of early embryonic lethal mutations. These approaches enable identification of the hematopoietic consequences of mutations with pleiotropic effects that might obscure examination of he-

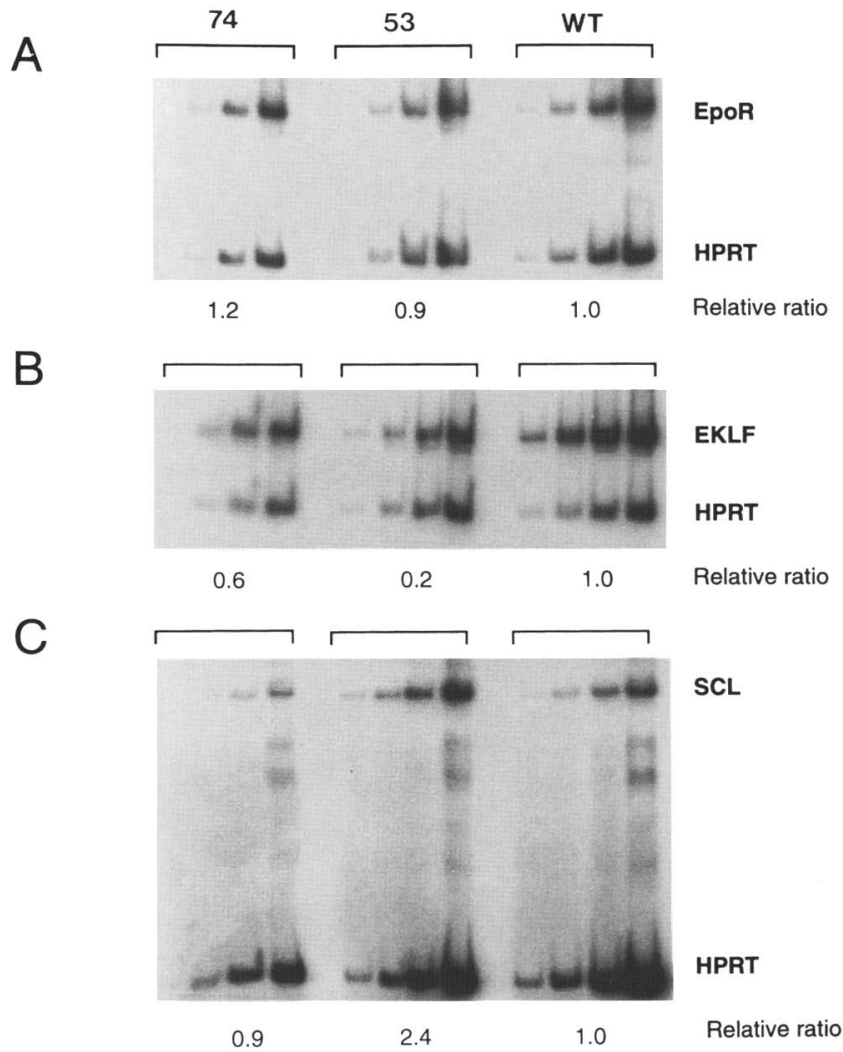

Figure 5. Expression of GATA target genes in wild-type and GATA-1 ${ }^{-}$proerythroblasts. RNA was purified from 3-day-old EryD colonies and analyzed by RT-PCR (Ferre 1992), as described in Materials and methods. Clones 74 and 53 are two independent GATA-1 ${ }^{-}$ES cell clones. Samples were examined after $20,22,24$, and 26 cycles of amplification. Relative ratios indicate the relative signal intensities for the gene of interest [ $(A) \operatorname{EpoR}(B)$ EKLF; $\mid C)$ SCL or tal-1] after normalization for the total amount of RNA, as reflected by the HPRT product signal intensity. Control experiments, in which reverse transcriptase was omitted from the cDNA synthesis step, failed to exhibit specific bands after 26 amplification cycles (not shown). 


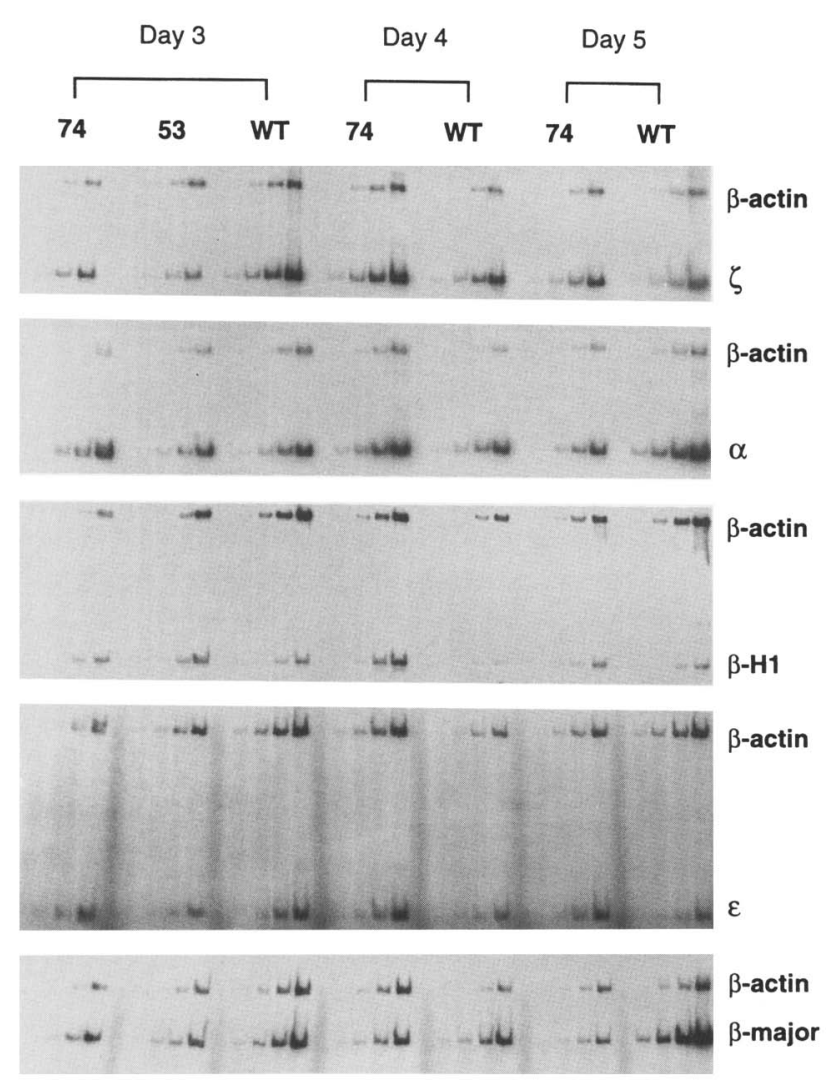

Figure 6. Globin gene expression in developing wild-type and GATA-1 - definitive erythroid colonies. RT-PCR analysis was performed on erythroid colonies as described in Fig. 5 and Materials and methods. Pools of $\sim 50$ erythroid colonies were analyzed for globin gene transcripts after 3, 4, and 5 days of colony development. PCR reactions were performed in the presence of $\beta$-actin primers and amplified for 14,16,18, and 20 cycles (first four lanes of each sample). The smears in the fifth lanes of the last two panels ( $\epsilon$ and $\beta$-major) represent control experiments in which no reverse transcriptase was added to the cDNA synthesis reaction; these samples were amplified for 20 cycles. Similar control experiments with $\zeta, \alpha$, and $\beta \mathrm{Hl}$ primer pairs also failed to produce specific PCR products (not shown). Quantitation of these data and additional experiments are summarized in $\mathrm{Ta}$ ble 1 .

matopoiesis in homozygous animals. Our application of improved in vitro culture assays for hematopoietic development extends in vivo approaches and has yielded novel insights into the consequences of GATA-1 loss.

\section{Role for GATA-1 in primitive erythropoiesis}

The EryP precursors were not detected in EBs derived from GATA-1 ${ }^{-}$ES cells, a finding formally consistent with a critical role for GATA-1 in the earliest period of primitive erythropoiesis. The pattern of GATA-1 expression during embryogenesis in vertebrates is consistent with this view. In the mouse the appearance of GATA-1 coincides with the onset of erythropoiesis in the yolk sac (Whitelaw et al. 1990), although the precise origin of the first GATA-1-positive cells is uncertain. In the frog embryo GATA-1 localizes to the ventral marginal zone and blood islands before the appearance of identifiable hematopoietic cells (Zon et al. 1991b; C. Kelley, K. Yee, J. DeCaprio, R.M. Harlan, and L.I. Zon, in prep.). Preliminary studies in zebrafish also reveal localization of GATA-1 to structures homologous to the extraembryonic yolk sac of the mouse $(\mathrm{H}$. Dietrich and L. Zon, pers. comm.). GATA-1 might be required for any, or several, steps in primitive erythropoiesis, including the initial decision of a stem cell to generate an erythroid progenitor, proliferation of the earliest progenitors, or cellular maturation.

An alternative interpretation suggests that the early block to primitive erythroid development reflects current culture conditions, which may be unfavorable for the development of early EryP precursors. Specifically, EryP colonies observed after replating of cells from wildtype EBs appear to represent late precursors (analogous to colony-forming units-erythroid), rather than earlier, burst-forming precursors that form a subset of the definitive lineage identified in colony assays. Therefore, as in the definitive erythroid lineage (see below), GATA-1 might be essential only in later EryP precursors. Until culture methods are developed to detect earlier primitive precursors, we cannot use in vitro assays to formally exclude the possibility that GATA-1 is dispensable at early stages of primitive erythropoiesis.

\section{Compensation by GATA-2 for loss of GATA-1}

The inability of GATA-1 - definitive precursors to complete their maturation in vivo and in vitro establishes an important role for the protein in erythroid development. Prior data have been interpreted to suggest that functional redundancy or potential compensatory mechanisms in GATA-1 ${ }^{-}$precursors are minimal (Pevny et al. 1991; Simon et al. 1992). Direct analysis of developmentally arrested definitive erythroid precursors recovered as pure hematopoietic colonies from the two-step in vitro differentiation assay refines this view and provides insights into the consequences of GATA- 1 loss that cannot be derived from prior approaches. The most striking findings to emerge are the approximately normal levels of transcripts for GATA target genes and the extraordinary increase in GATA-2 expression in the arrested precursors. Several important inferences derive from these observations:

First, relating these findings, we postulate that GATA-2 participates in transcription of presumptive GATA target genes, such as EpoR, EKLF, SCL, and globins, in GATA-1 ${ }^{-}$cells. Therefore, with regard to their function in vivo, GATA-1 and GATA-2 proteins are largely interchangeable, despite virtual nonhomology outside the conserved two-finger DNA-binding domains (Yamamoto et al. 1990; Zon et al. 1991b). This conclusion is generally consistent with functional assays of trans-activation of various reporter constructs by GATA factors, which have not as yet identified promoter or cell specificity in their action (Dorfman et al. 1992; Orkin 
Table 1. Relative ratios of globin RT-PCR products in developing erythroid colonies

\begin{tabular}{|c|c|c|c|c|c|c|c|}
\hline \multirow[b]{3}{*}{ Globin $^{a}$} & \multicolumn{7}{|c|}{ Colony age $^{b}$} \\
\hline & \multicolumn{3}{|c|}{ day 3} & \multicolumn{2}{|c|}{ day 4} & \multicolumn{2}{|c|}{ day 5} \\
\hline & WT & $\begin{array}{l}\text { GATA-1 - } \\
\text { (clone 74) }\end{array}$ & $\begin{array}{l}\text { GATA-1 - } \\
\text { (clone 53) }\end{array}$ & WT & $\begin{array}{l}\text { GATA-1- } \\
\text { (clone } 74 \text { ) }\end{array}$ & WT & $\begin{array}{l}\text { GATA-1 }^{-} \\
\text {(clone } 74 \text { ) }\end{array}$ \\
\hline \multicolumn{8}{|l|}{$\beta-\mathrm{Hl}$} \\
\hline experiment 1 & 1.0 & 3.9 & 4.2 & 1.1 & 2.3 & 0.7 & 2.5 \\
\hline experiment 2 & 1.0 & 5.2 & N.D. & 1.8 & N.D. & 2.4 & 6.8 \\
\hline \multicolumn{8}{|l|}{$\epsilon$} \\
\hline experiment 1 & 1.0 & 4.0 & 1.1 & 2.0 & 1.7 & 0.7 & 2.3 \\
\hline experiment 2 & 1.0 & 3.4 & N.D. & N.D. & N.D. & N.D. & N.D. \\
\hline \multicolumn{8}{|l|}{$\beta$-major } \\
\hline experiment 1 & 1.0 & 1.8 & 1.0 & 3.4 & 0.6 & 5.1 & 0.7 \\
\hline experiment 2 & 1.0 & N.D. & N.D. & 1.9 & N.D. & 3.6 & 0.8 \\
\hline \multicolumn{8}{|l|}{$\zeta$} \\
\hline experiment 1 & 1.0 & 1.0 & 0.2 & 1.9 & 1.3 & 0.7 & 0.9 \\
\hline experiment 2 & 1.0 & 1.3 & N.D. & 1.1 & N.D. & 1.8 & 0.8 \\
\hline \multicolumn{8}{|l|}{$\alpha$} \\
\hline experiment 1 & 1.0 & 3.4 & 1.4 & 3.1 & 1.7 & 2.4 & 1.9 \\
\hline experiment 2 & 1.0 & 5.7 & N.D. & 2.6 & 2.6 & 6.2 & 1.9 \\
\hline
\end{tabular}

EryD colonies derived from replating 6-day-old embryoid bodies in Epo/KL were isolated after 3, 4, and 5 days of colony development, pooled into groups, and analyzed for the presence of globin mRNAs by RT-PCR. The relative ratios of globin RT-PCR products derived from each colony pool are shown, with the day 3 wild-type (WT) sample arbitrarily assigned a value of 1.0. Values are normalized with respect to $\beta$-actin RT-PCR products to adjust for the amount of RNA present in each sample. These data enable comparison of the relative amounts of the same globin gene among different samples but do not allow estimation of the relative amounts of different globin genes in samples because of differences in efficiency of PCR amplification between different genes and different primer pairs.

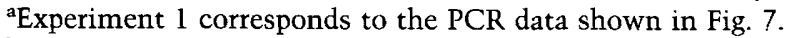

b(N.D.) Not done.

1992). Whether subtle differences in DNA-binding specificities of these factors, recently demonstrated in vitro with selected binding sites (Ko and Engel 1993; Merika and Orkin 1993), are relevant to differential utilization of these proteins in vivo is uncertain.

Second, expression of globin genes in the absence of GATA-1 implies that productive interactions occur between the LCRs and the proximal regulatory elements of the downstream globin genes. We infer that GATA-2 functions in place of GATA-1 within these complexes. In our prior study of differentiation of GATA-1 ${ }^{-}$ES cells in whole EBs we did not detect appreciable globin RNAs by RNase protection assays (Simon et al. 1992). Several factors are likely to account for this. In whole EBs hematopoietic cells represent only a minority of the total cells present. More important, developmentally arrested precursors die and hence contribute far less than their fraction of the total population. In addition, we have noted increased death of precursors within mutant EBs cultured at higher densities (data not shown), a phenomenon that biases against a contribution by mutant erythroid cells harvested from EBs at late times. Although the present data indicate that both GATA-1 and GATA-2 can participate in globin gene expression, the proteins may not be entirely interchangeable in this regard, as suggested by the relative increase in $\beta \mathrm{Hl}$ and decrease in $\beta$-major transcripts in arrested precursors. Subtle differences in the profile of globin genes expressed may ensue upon substitution of GATA-2 for GATA-1.
Third, when taken together with its high level expression in multipotential hematopoietic progenitors, the realization that GATA-2 can function in transcription of globin and nonglobin erythroid-expressed genes raises the possibility that a succession of GATA factors acting at particular targets may normally occur during cellular differentiation. The successive action of related transcriptional regulators that differ subtly in their properties may provide a finer level of regulation of target genes during cellular development than that achievable with a single factor. In the context of globin gene regulation, for example, GATA-2 might prepare LCR elements in undifferentiated embryonic cells, hematopoietic stem cells, or early progenitor cells to be acted on by GATA-1 during the later stages of erythroid maturation. Thus, LCRs might be maintained in a poised state before maturation of precursors along a single lineage, a model consistent with the observation that LCR elements are DNase I hypersensitive in multipotential cells (Jimenez et al. 1992).

Fourth, our data provide the first evidence for cross regulation between members of the GATA family. Specifically, markedly increased expression of GATA-2 in arrested precursors strongly suggests that GATA-1 represses GATA-2 transcription, either by direct or indirect means, during normal erythroid development. The lack of a compensatory increase in GATA-3 expression demonstrates that cross-regulation is selective. Repression of GATA-2 expression mediated by GATA-1 may 
A

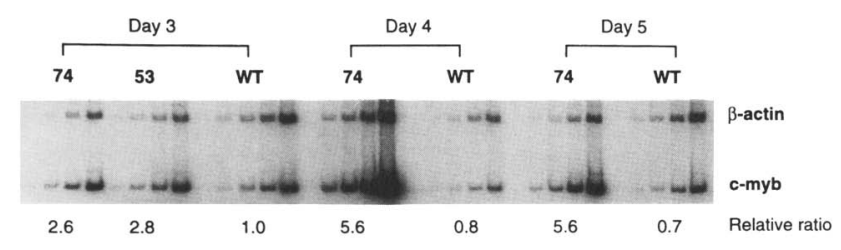

B

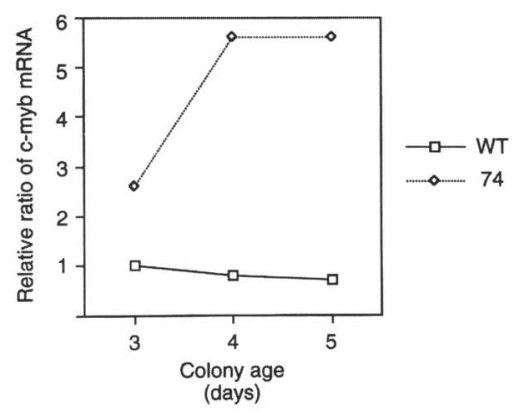

Figure 7. c-myb mRNA is increased in GATA-1 ${ }^{-}$erythroid cells. $(A)$ Pools of $\sim 50$ erythroid colonies were analyzed by RTPCR for c-myb transcripts after 3,4 , and 5 days of colony development, as described in Fig. 6 and Materials and methods. Samples were amplified for six cycles in the presence of $c-m y b$ primers. Primers for $\beta$-actin were then added, and aliquots were removed for analysis after an additional 14, 16, 18, and $20 \mathrm{cy}$ cles. Relative ratios indicate the relative signal intensities for c-my $b$ after normalization against the $\beta$-actin signal intensity. The 3-day wild-type sample was arbitrarily assigned a value of 1.0. (B) Relative ratios of $c-m y b$ mRNA versus colony age.

account for the progressive decrease in GATA-2 transcription that normally accompanies the rise in GATA-1 occurring during erythroid maturation (Sposi et al. 1992; Dalyot et al. 1993).

Possible mechanisms for developmental arrest in the absence of GATA-1

If increased expression of GATA-2 compensates for loss of GATA-1, why is definitive erythroid maturation arrested in the mutant cells? Several explanations are possible. For one, although the GATA-2 level is dramatically elevated relative to normal proerythroblasts, it may never achieve the abundance of GATA-1 seen in late erythroid precursors. If trans-activation of specific target genes requires a high concentration of a GATA factor, critical protein deficiencies and a developmental block will ensue. Alternatively, some targets, as yet unidentified, may normally be transcribed selectively by GATA-1 rather than by GATA-2. Therefore, dedicated roles for GATA-1 may be functionally important late in cellular maturation.

An alternative mechanism related to the marked elevation of GATA-2 may account for the developmental arrest. Forced expression of GATA-2, but not GATA-1 or
GATA-3, in chicken erythroid precursors promotes cellular proliferation and blocks subsequent maturation (Briegel et al. 1993). In a similar manner, derepression of GATA-2 in GATA-1 ${ }^{-}$cells may directly inhibit terminal erythroid maturation. Accordingly, an attempt to compensate for GATA-1 loss may paradoxically lead to maturation arrest.

The observation that c-myb mRNA is up-regulated in GATA-1 ${ }^{-}$erythroid cells suggests another pathway through which development of the mutant cells may be arrested. The decrease in c-myb expression that normally accompanies erythroid development is thought to be a prerequisite for terminal maturation (Clarke et al. 1988; Gewirtz and Calabretta 1988; Todokoro et al. 1988; McClinton et al. 1990|. Forced expression of c-myb to modest levels is capable of blocking induced differentiation of erythroleukemia cells. Hence, higher endogenous $c-m y b$ levels, caused by either positive regulation by GATA-2 or loss of repression by GATA-1, might contribute to the developmental block.

We speculate that several of the mechanisms discussed above may act in concert to produce the GATA$1^{-}$erythroid phenotype. Thus, derepression of GATA-2 and $\mathrm{c}-\mathrm{my} b$ may promote cellular proliferation, whereas lack of a critical GATA-1-specific target gene may impair viability of mutant proerythroblasts. This combination of conflicting or incompatible growth signals could potentially induce cell death, as has been observed in a variety of other cellular systems (White 1993).

The proerythroblast arrest of GATA-1 ${ }^{-}$ES cells is not merely a peculiarity of the in vitro differentiation system used here. In other experiments to be reported elsewhere, ES-derived arrested proerythroblasts have been seen in mixed hematopoietic colonies obtained from the fetal liver of wild-type-GATA-1 - chimeras (L. Pevny, C.-S. Lin, V. D-Agati, M.C. Simon, S.H. Orkin, and F. Constantini, in prep.). GATA-1 ${ }^{-}$colonies containing proerythroblasts quantitatively replace wild-type colonies that contain mature red blood cells. In the replating assay used here, the arrested cells can be captured in pure form for analysis.

\section{Regulatory networks of GATA factors in erythropoiesis}

Development of primitive erythroid precursors from a stem-progenitor cell in the yolk sac may be predominantly dependent on GATA-1. In definitive erythropoiesis, either GATA-1 or GATA-2 is sufficient to permit development of proerythroblasts from earlier stem-progenitor cells. Thus, functional redundancy appears intrinsic to the early stages of definitive lineage development. GATA-1 expression, however, is required to complete maturation to the red cell. An essential role for GATA-1 in late erythroblast development is consistent with the burst of GATA-1 expression that accompanies normal erythroid maturation (Sposi et al. 1992; Dalyot et al. 1993).

Beyond its role as a compensatory factor for GATA-1 in the definitive erythroid lineage, GATA-2 serves in 

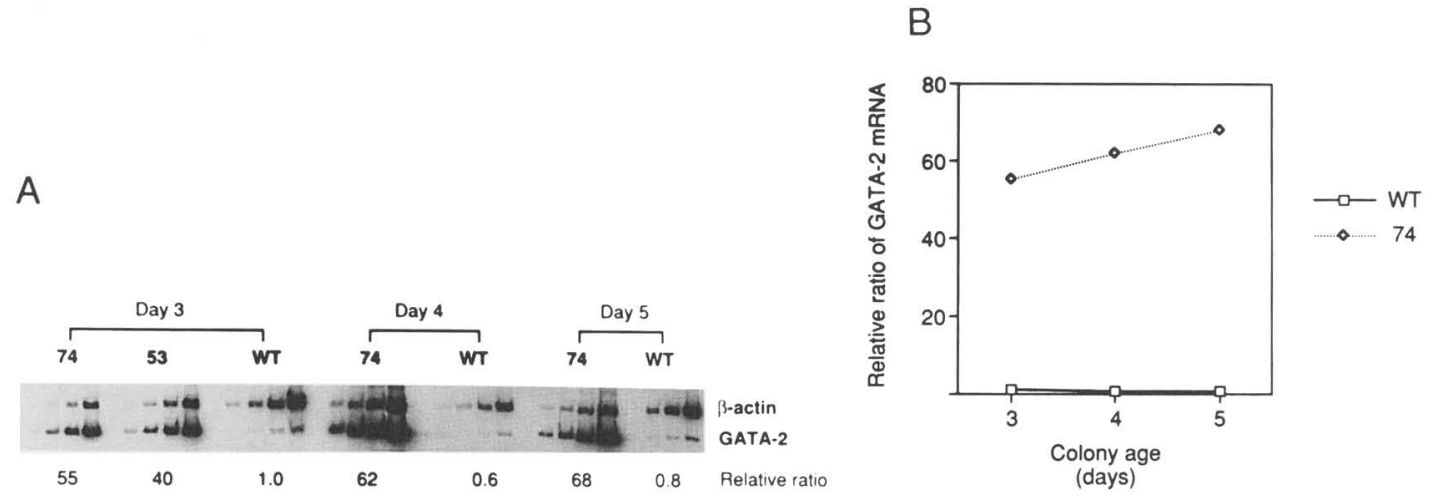

C

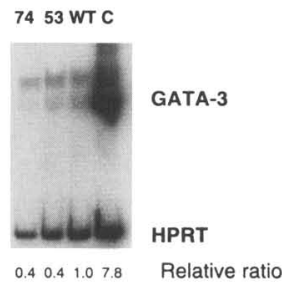

Figure 8. Expression of the transcription factor GATA-2, but not GATA-3, is markedly up-regulated in GATA-1 ${ }^{-}$definitive erythroid cells. Wild-type (WT) and GATA-1 ${ }^{-}$erythroid colonies at 3,4, and 5 days of age were analyzed by RT-PCR as described in Fig. 6 and Materials and methods. (A) GATA-2 expression in GATA- ${ }^{-}$(clones 74 and 53) and wild-type (WT) EryD colonies. Samples were amplified for four cycles in the presence of GATA-2 primers. Primers for $\beta$-actin were added and aliquots removed for analysis after an additional 14,16,18, and 20 cycles. $(B)$ Summary of the relative expression of GATA-2 RNA in wild-type and GATA-1 ${ }^{-}$colonies vs. colony age. $(C)$ GATA-3 expression. Samples containing GATA-3 and HPRT primers were analyzed after 28 amplification cycles. Lane $C$ contains cDNA from the T-cell hybridoma line By155.16, used as a positive control for GATA-3 mRNA.

vivo as an important factor for stem-progenitor cell proliferation or maintenance. Hematopoiesis from GATA$2^{-}$ES cells is nearly ablated (F.-Y. Tsai, G. Keller, F.C. Kuo, M. Weiss, J.-Z. Chen, M. Rosenblatt, F. Alt, and S.H. Orkin, in prep.). This effect is most pronounced in definitive progenitors, but also evident in primitive progenitors. Taken together with our finding that GATA-2 is overexpressed in GATA-1 ${ }^{-}$definitive proerythroblasts, these data suggest the existence of a potentially complex regulatory network among the GATA family transcription factors, in which GATA-1 may repress GATA-2, and GATA-2 may activate genes controlling or signaling proliferation in progenitor cells.

The cross-regulation and potential redundancy of GATA- 1 and GATA- 2 in the early stages of the definitive erythroid pathway are reminiscent of the relationship of myogenic bHLH factors in muscle development. In vivo, Myf-5 can largely substitute for the function of MyoD in muscle development (Rudnicki et al. 1992). This occurs in the setting of a modest ( $\sim 3.5$-fold) increase in Myf-5 expression in MyoD null muscle. A different member of the myogenic bHLH family, myogenin, is necessary in vivo to complete muscle differentiation (Hasty et al. 1993; Nabeshima et al. 1993). In the definitive erythroid lineage, GATA-1, rather than another member of the GATA family, is apparently required to complete cellular maturation. Thus, in both systems potential redundancy is imposed by related transcription factors; yet, terminal maturation requires a specific member of the family. Such a complex layered pattern of regulation appears to be characteristic of mammalian developmental programs.

The experimental strategy we have pursued is a general approach to phenotypic characterization of targeted mutations affecting hematopoietic development, particularly those that are lethal in the homozygous state. As demonstrated here, study of pure hematopoietic cells of mutant origin, particularly where cellular differentiation is blocked, provides a route to uncovering compensatory mechanisms and complex regulatory networks. Within the context of a chimera or a homozygous animal these cells are inaccessible. The ES cell in vitro differentiation methods will also prove useful in unraveling the complexities of other developmental processes. For example, phenotypic markers for myogenesis, cardiogenesis, vasculogenesis, and angiogenesis have been detected in embryoid bodies (Risau et al. 1988; Wang et al. 1992; MillerHance et al. 1993; Mutchuchamy et al. 1993). As techniques are developed to generate cells representative of other organ systems in vitro from ES cells, examination of the effects of mutations within the context of developing embryoid bodies will become an increasingly rich approach with which to complement whole animal studies.

\section{Materials and methods}

\section{Cells}

Undifferentiated wild-type and GATA-1 ${ }^{-}$clones 53 and 74 (Pevny et al. 1991) of the ES cell line CCE (Robertson et al. 1986) were grown on gelatin-treated flasks in Dulbecco's modified Eagle medium supplemented with mouse leukemia inhibitory factor (LIF; $1 \%$ conditioned medium from a LIF-transfected CHO cell line), $15 \%$ fetal calf serum, and $1.5 \times 10^{-4} \mathrm{M}$ monothioglycerol. Two days before setting up an in vitro differentiation assay, cells were passaged into Iscove's modified Dulbecco's medium containing the supplements noted above.

\section{In vitro differentiation of ES cells}

The two-step in vitro differentiation assay was performed as described previously (Keller et al. 1993). EryP precursors were quantitated after replating disaggregated embryoid bodies into methylcellulose media containing recombinant Epo $(2 \mathrm{U} / \mathrm{ml})$. Replating into a mixture of growth factors including Epo, KL 
Weiss et al.

Table 2. Oligonucleotide primers used for RT-PCR

\begin{tabular}{|c|c|c|c|c|}
\hline Gene & $\begin{array}{l}\text { Size } \\
(\mathrm{bp})^{\mathrm{a}}\end{array}$ & $5^{\prime}$-Sequence & $3^{\prime}$-Sequence & Reference \\
\hline$\alpha$-globin & 331 & $\begin{array}{l}\text { 5'-CTCTCTGGGGAAGACAAAAGCA } \\
\text { AC-3' }\end{array}$ & $\begin{array}{l}\text { 5'-GGTGGCTAGCCAAGGTCACCAG } \\
\text { CA- } 3^{\prime}\end{array}$ & $\begin{array}{l}\text { Nishioka and } \\
\text { Leder }(1979)\end{array}$ \\
\hline$\beta$-actin & 938 & 5'-GTGACGAGGCCCAGAGCAAGAG-3' & 5'AGGGGCCGGACTCATCGTACTC-3' & Alonso et al. (1986) \\
\hline$\beta \mathrm{H} 1$ globin & 265 & 5'-AGTCCCCATGGAGTCAAAGA-3' & 5'-CTCAAGGAGACCTTTGCTCA-3' & Hill et al. (1984) \\
\hline$\beta$-major globin & 578 & 5'-CTGACAGATGCTCTCTTGGG-3' & 5'-CACAACCCCAGAAACAGACA-3' & Konkel et al. (1978) \\
\hline EKLF & 359 & 5'-TCGCCGGAGACGCAGGCT-3' & 5'-CCCAGTCCTTGTGCAGGA-3' & Miller and Bieker (1993) \\
\hline EpoR & 452 & $5^{\prime}$-GGACACCTACTTGGTATTGG-3' & 5'-GACGTTGTAGGCTGGAGTCC-3' & D'Andrea et al. (1989) \\
\hline$\epsilon$-globin (Y-2) & 122 & $\begin{array}{l}\text { 5'-GGAGAGTCCATTAAGAACCTAG } \\
\text { ACAA-3' }\end{array}$ & $\begin{array}{l}\text { 5'-CTGTGAATTCATTGCCGAAG } \\
\text { TGAC-3' }\end{array}$ & Hansen et al. (1982) \\
\hline GATA-2 & $\sim 720$ & $\begin{array}{l}\text { 5'-CGGAATTCGACACACCACCCGA } \\
\text { TACCCACCTAT-3' }\end{array}$ & $\begin{array}{l}\text { 5'-CGGAATTCGCCTACGCCATGG } \\
\text { CAGTCACCATGCT-3' }\end{array}$ & $\begin{array}{l}\text { F.Y. Tsai, and S.H. } \\
\text { Orkin (unpubl.) }\end{array}$ \\
\hline GATA-3 & 566 & $\begin{array}{l}\text { 5'-ACGTCTCACTCTCGAGGCAGCA } \\
\text { TG-3' }\end{array}$ & $\begin{array}{l}\text { 5'-GAAGTCCTCCAGCGCGTCATG } \\
\text { CAC-3' }\end{array}$ & Ko et al. $(1991)$ \\
\hline HPRT & 249 & 5'-CACAGGACTAGAACACCTGC-3' & 5'-GCTGGTGAAAAGGACCTCT-3' & Konecki et al. (1982) \\
\hline c-Myb & 475 & $\begin{array}{l}\text { 5'-GAGCTTGTCCAGAAATATGGTC } \\
\text { CGAAG-3' }\end{array}$ & $\begin{array}{l}\text { 5'-GGCTGCCGCAGCCGGCTGAG } \\
\text { GGAC-3' }\end{array}$ & Lavu and Reddy $(1986)$ \\
\hline SCL & 914 & 5'-CAGCAGAATGTGAATGGGGCAT-3' & 5'-TTGACTCTCCACAGCAGCT- $3^{\prime}$ & Begley et al. (1991) \\
\hline$\zeta$-globin & 370 & 5'-GCTCAGGCCGAGCCCATTGG-3' & 5'-TAGCGGTACTTCTCAGTCAG-3' & Leder et al. (1985) \\
\hline
\end{tabular}

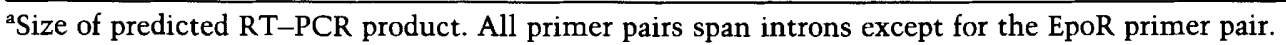

$(250 \mathrm{ng} / \mathrm{ml}$ recombinant or $1 \%$ conditioned medium from $\mathrm{KL}$ producing CHO cells), interleukin-1 (IL-1) $\left(10^{3} \mathrm{U} / \mathrm{ml}\right), \mathrm{IL}-3\left(10^{2}\right.$ $\mathrm{U} / \mathrm{ml}$ ), G-CSF (granulocyte colony-stimulating factor) $\left(10^{3}\right.$ $\mathrm{U} / \mathrm{ml}$ ), GM-CSF (granulocyte-macrophage CSF) $(15 \mathrm{U} / \mathrm{ml}$ ), and M-CSF macrophage CSF) $(100 \mathrm{U} / \mathrm{ml})$ supported the development of EryD, macrophage, and mixed colonies. The EryD colonies required Epo and KL for optimal development. For morphologic examination colonies were aspirated from methylcellulose, gently spread on a glass slide with a stream of compressed air, and stained with May-Grunwald-Giemsa.

\section{RT-PCR analysis}

For RT-PCR analysis (Saiki et al. 1985; Ferre et al. 1992) of RNA from EryD colonies, 6-day-old EB were replated into Epo and KL. These conditions yield erythroid colonies almost exclusively and, therefore, minimize the possibility of contamination by nonerythroid cells. Because wild-type EryP colonies are abundant in these replatings (500-1000 colonies per dish), it is possible that a few were inadvertantly sampled. Approximately 50 erythroid colonies were removed from methylcellulose cultures with a micropipette and placed into $200 \mu \mathrm{l}$ of phosphate-buffered saline (PBS). Cell viability was determined by mixing a small aliquot with eosin solution and counting in a hemocytometer. After centrifugation of the cells, $20 \mu \mathrm{g}$ of glycogen (Boehringer Mannheim, GmbH) was added as carrier, and RNA was isolated by acid-phenol extraction (Chomczynski and Sacchi 1987). Complementary DNA was synthesized by Moloney murine leukemia vins reverse transcriptase (GIBCO/BRL, Gaithersburg, $\mathrm{MD}$ ) with oligo(dT) as primer, according to the manufacturer's instructions. The cDNA mixtures were purified by phenol-chloroform extraction before PCR. PCR reactions were performed using Taq DNA polymerase (Boehringer Mannheim) according to the manufacturer's instructions. Each reaction contained cDNA derived from 50 to 100 cells, reaction buffer supplied by the manufacturer with $\mathrm{Mg}^{2+} 2 \mathrm{mM}$ final concentration, $0.2 \mu \mathrm{M}$ oligonucleotide primers, $200 \mu \mathrm{M}$ each $\mathrm{dNTP}$, and $0.1 \mu \mathrm{Ci}\left[\alpha^{-32} \mathrm{P}\right] \mathrm{dCTP}(3000 \mathrm{Ci} / \mathrm{mm}$; Amersham, Arlington
Heights, IL). Reaction mixtures contained two sets of primers: one directed to the transcript of interest, and one for a constitutively expressed transcript, either HPRT or $\beta$-actin. The primers used in our experiments are listed in Table 2 . Reactions were cycled at $94^{\circ} \mathrm{C}$ for $30 \mathrm{sec}, 55^{\circ} \mathrm{C}$ for $30 \mathrm{sec}$, and $72^{\circ} \mathrm{C}$ for $60 \mathrm{sec}$ using a PTC-100 thermal controller (MJ Research, Watertown, MA). Aliquots were removed after various cycle numbers (determined empirically to maintain amplification in a linear range) and electrophoresed through a $4 \%$ polyacrylamide gel. Image analysis was performed using a PhosphorImager and ImageQuant software (Molecular Dynamics, Sunnyvale, CA). Quantitation calculations were limited to PCR samples in which amplification was proceeding linearly. This analysis permits comparison of the relative levels of specific RNAs among different samples but does not enable accurate quantitation of the absolute level of any mRNA or the relative levels of different mRNAs due to possible differences in amplification efficiencies of primer pairs. Results of PCR quantitations were similar regardless of whether HPRT or $\beta$-actin transcripts were used as the internal control. Control experiments, in which reverse transcriptase was omitted from the cDNA synthesis reaction, failed to show specific PCR products. The murine T-cell hybridoma line, By155.16 (Sleckman et al. 1987), used as a positive control for GATA-3 mRNA, was supplied by Dr. Steven Burakoff (Dana-Farber Cancer Institute, Boston, MA).

\section{Acknowledgments}

M.J.W. and G.K. contributed equally to this work. We thank Genetics Institute, Amgen, and Immunex Corporation for generous gifts of hematopoietic growth factors used in these studies. This work was supported in part by grants from the $\mathrm{Na}$ tional Institutes of Health to G.K. (R01 DK-43285) and S.H.O., who is an Investigator of the Howard Hughes Medical Institute.

The publication costs of this article were defrayed in part by payment of page charges. This article must therefore be hereby 
marked "advertisement" in accordance with 18 USC section 1734 solely to indicate this fact.

\section{References}

Alonso, S., A. Minty, Y. Bourlet, and M.E. Buckingham. 1986. Comparison of three actin-coding sequences in the mouse: Evolutionary relationships between the actin genes of warmblooded vertebrates. I. Mol. Evol. 23: 11-22.

Aplan, P.D., K. Nakahara, S.H. Orkin, and I.R. Kirsch. 1992. The SCL gene product: A positive regulator of erythroid differentiation. EMBO J. 11: 4073-4081.

Begley, C.G., P.D. Aplan, S.M. Denning, B.F. Haynes, T.A. Waldmann, and I.R. Kirsch. 1989. The gene SCL is expressed during early hematopoiesis and encodes a differentiationrelated DNA-binding motif. Proc. Natl. Acad. Sci. 86: 10128-10132.

Begley, C.G., J. Visvader, A.R. Green, P.D. Aplan, D. Metcalf, I.R. Kirsch, and N. Gough. 1991. Molecular cloning and chromosomal location of the mouse homolog of the human helix-loop-helix gene SCL. Proc. Natl. Acad. Sci. 88: 869873.

Briegel, K., K.-C. Lim, C. Plank, H. Beug, J. Engel, and M. Zenke. 1993. Ectopic expression of a conditional GATA-2/estrogen receptor chimera arrests erythroid differentiation in a hormone-dependent manner. Genes \& Dev. 7: 1097-1109.

Brotherton, T.W., D.H.K. Chui, J. Gauldie, and M. Patterson. 1979. Hemoglobin ontogeny during normal mouse fetal development. Proc. Natl. Acad. Sci. 76: 2853-2857.

Burkert, U., R.T. von Ruden, and E.F. Wagner. 1991. Early fetal hematopoietic development from in vitro differentiated embryonic stem cells. New Biol. 3: 698-708.

Capecchi, M.R. 1989. Altering the genome by homologous recombination. Science 244: 1288-1292.

Chomczynski, P. and N. Sacchi. 1987. Single-step method of RNA isolation by acid guanidinium thiocyanate-phenolchloroform extraction. Anal. Biochem. 162: 156-159.

Clarke, M.F., J.F. Kukowska-Latallo, E. Westin, M. Smith, and E.V. Prochownik. 1988. Constitutive expression of a c-myb cDNA blocks Friend murine erythroleukemia cell differentiation. Mol. Cell. Biol. 8: 884-892.

D'Andrea, A.D., H.F. Lodish, and G.C. Wong. 1989. Expression cloning of the murine erythropoietin receptor. Cell 57: 227285.

Dalyot, N., E. Fibach, A. Ronchi, E.A. Rachmilewitz, S. Ottolenghi, and A. Oppenheim. 1993. Erythropoietin triggers a burst of GATA-1 in normal human erythroid cells differentiating in tissue culture. Nucleic Acids Res. 21: 4031-4037.

Doetschman, T.C., H. Eistetter, M. Katz, W. Schmidt, and R. Kemler. 1985. The in vitro development of blastocyst-derived embryonic stem cell lines: Formation of visceral yolk sac, blood islands, and myocardium. J. Embryol. Exp. Morphol. 87: 27-45.

Dorfman, D.M., D.B. Wilson, G.A. Bruns, and S.H. Orkin. 1992. Human transcription factor GATA-2. Evidence for regulation of preproendothelin-1 gene expression in endothelial cells. J. Biol. Chem. 267: 1279-1285.

Ellis, J., D. Talbot, N. Dillon, and F. Grosveld. 1993. Synthetic human $\beta$-globin $5^{\prime} \mathrm{HS} 2$ constructs function as locus control regions only in multicopy transgene concatamers. $E M B O J$. 12: $127-134$.

Evans, T. and G. Felsenfeld. 1989. The erythroid-specific transcription factor eryfl: A new finger protein. Cell 58: 877885.

1991. Trans-activation of a globin promoter in non-ery- throid cells. Mol. Cell. Biol. 11: 843-853.

Evans, T., M. Reitman, and G. Felsenfeld. 1988. An erythrocytespecific DNA-binding factor recognizes a regulatory sequence common to all chicken globin genes. Proc. Natl. Acad. Sci. 85: 5976-5980.

Ferre, F. 1992. Quantitative or semi-quantitative PCR: Reality versus myth. PCR Methods Applic. 2: 1-9.

Fong, T.C. and B.M. Emerson. 1992. The erythroid-specific protein cGATA-1 mediates distal enhancer activity through a specialized $\beta$-globin TATA box. Genes \& Dev. 6: 521-532.

Gewirtz, A.M. and B. Calabretta. 1988. A c-myb antisense oligodeoxynucleotide inhibits normal human hematopoiesis in vivo. Science 242: 1303-1306.

Godin, I.E., J.A. Garcia-Porrero, A. Coutinho, F. DieterlenLievre, and M.A.R. Marcos. 1993. Para-aortic splanchnopleura from early mouse embryos contains Bla cell progenitors. Nature 364: 67-70.

Grosveld, F., G.B. van Assendelft, D.R. Greaves, and B. Kollias. 1987. Position-independent, high-level expression of the human beta-globin gene in transgenic mice. Cell 51: 975-985.

Hansen, J.N., D.A. Konkel, and P. Leder. 1982. The sequence of a mouse embryonic $\beta$-globin gene. J. Biol. Chem. 257: 10481052.

Hasty, P., A. Bradley, J.H. Morris, D.G. Edmonson, J.M. Venuti, E.N. Olson, and W.H. Klein. 1993. Muscle deficiency and neonatal death in mice with a targeted mutation in the myogenin gene. Nature 364: 501-506.

Higgs, D.R., W.G. Wood, A.P. Jarman, J. Sharpe, J. Lida, I.-M Pretorius, and H. Ayyub. 1990. A major positive regulatory region is located far upstream of the human $\alpha$-globin gene locus. Genes \& Dev. 4: 1588-1601.

Hill, A., S.C. Hardies, S.J. Phillips, M.G. Davis, C.A. Hutchison III, and M.H. Edgell. 1984. Two mouse early embryonic ß-globin gene sequences. I. Biol. Chem. 259: 3739-3747.

Ho, I.-C., P. Vorhees, N. Marin, B.K. Oakley, S.-F. Tsai, S.H. Orkin, and J.M. Leiden. 1991. Human GATA-3: A lineagerestricted transcription factor that regulates the expression of the T cell receptor $\alpha$ gene. EMBO J. 10: 1187-1192.

Jarman, A.P., W.G. Wood, J.A. Sharpe, G. Gourdon, H. Ayyub, and D.R. Higgs. 1991. Characterization of the major regulatory element upstream of the human $\alpha$-globin gene cluster. Mol. Cell. Biol. 11: 4679-4689.

Jimenez, G., S.D. Griffiths, A.M. Ford, M.F. Greaves, and T. Enver. 1992. Activation of the $\beta$-globin locus control region precedes commitment to the erythroid lineage. Proc. Natl. Acad. Sci. 89: 10618-10622.

Joulin, V., D. Bories, J.-F. Eleouet, M.-C. Labastie, S. Chretien, M.-G. Mattei, and P.-H. Romeo. 1991. A T-cell specific TCR- $\delta$ DNA binding protein is a member of the human GATA family. EMBO $\%$ 10: 1809-1816.

Keller, G., M. Kennedy, T. Papayannopoulou, and M.V. Wiles. 1993. Hematopoietic differentiation during embryonic stem cell differentiation in culture. Mol. Cell Biol. 13: 472-486.

Knezetic, J.A. and G. Felsenfeld. 1989. Identification and characterization of a chicken $\alpha$-globin enhancer. Mol. Cell. Biol. 9: 893-901.

Ko, L. and J. Engel. 1993. DNA-binding specificities of the GATA transcription factor family. Mol. Cell. Biol. 13: 40114022.

Ko, L.J., M. Yamamoto, M.W. Leonard, K.M. George, P. Ting, and J.D. Engel. 1991. Murine and human T-lymphocyte GATA-3 factors mediate transcription through a cis-regulatory element within the human T-cell receptor $\delta$ gene enhancer. Mol. Cell. Biol. 11: 2778-2784.

Konecki, D.S., J. Brennand, J.C. Fuscoe, C.T. Caskey, and A.C. Chinault. 1982. Hypoxanthine-guanine phosphoribosyl- 
transferase genes of mouse and Chinese hamster: Construction and sequence analysis of cDNA recombinants. Nucleic Acids Res. 10: 6763-6775.

Konkel, D.A., S.M. Tilghman, and P. Leder. 1978. The sequence of the chromosomal mouse beta-globin major gene: Homologies in capping, and poly(A) sites. Cell 15: 1125-1132.

Lavu, S. and E.P. Reddy. 1986. Structural organization and nucleotide sequence of mouse c-myb oncogene: Activation in ABPL tumors is due to viral integration in an intron which results in the deletion of the $5^{\prime}$-coding sequences Nucleic Acids Res. 14: 5309-5320.

Leder, A., A. Kou, M.M. Shen, and P. Leder. 1992. In situ hybridization reveals co-expression of embryonic and adult $\alpha$ genes in the earliest murine erythrocyte precursors. Development 116: 1041-1049.

Leder, A., L. Weir, and P. Leder. 1985. Characterization, expression, and evolution of the mouse embryonic $\zeta$-globin gene. Mol. Cell. Biol. 5: 1025-1033.

Leonard, M., M. Brice, J.D. Engel, and T. Papayannopoulou. 1993. Dynamics of GATA transcription factor expression during erythroid differentiation. Blood 82: 1071-1079.

Lüscher, B. and R.N. Eisenman. 1990. New light on Myc and Myb. Part II. Myb. Genes \& Dev. 4: 2235-2241.

Martin, D.I.K., S.-F. Tsai, and S.H. Orkin. 1989. Increased $\gamma$-globin expression in a nondeletion HPFH mediated by an erythroid-specific DNA-binding factor. Nature 338: 435438.

Martin, D.I.K., L.I. Zon, G. Mutter, and S.H. Orkin. 1990. Expression of an erythroid transcription factor in megakaryocytic and mast cell lineages. Nature 344: 444-446.

McClinton, D., J. Stafford, L. Brents, T.P. Bender, and W.M. Kuehl. 1990. Differentiation of mouse erythroleukemia cells is blocked by late up-regulation of a c-myb transgene. Mol. Cell. Biol. 10: 705-710.

Medvinsky, A.L., N.L. Samoylina, A.M. Muller, and E.A. Dzierzak. 1993. An early pre-liver intraembryonic source of CFU-S in the developing mouse. Nature 364: 64-66.

Merika, M. and S.H. Orkin. 1993. DNA-binding specificity of GATA-family transcription factors. Mol. Cell. Biol. 13: 3999-4010.

Miller, I.J. and J.J. Bieker. 1993. A novel, erythroid cell-specific murine transcription factor that binds to the CACCC element and is related to the Kruppel family of nuclear proteins. Mol. Cell. Biol. 13: 2776-2786.

Miller-Hance, W.C., M. LaCorbiere, S.J. Fuller, S.M. Evans, G. Lyons, C. Schmidt, J. Robbins, and K.R. Chien. 1993. In vitro chamber specification during embryonic stem cell cardiogenesis: Expression of the ventribular myosin light chain-2 gene is independent of heart tube formation. I. Biol. Chem. 268: 25244-25252.

Mucenski, M.L., K. McLain, A.B. Kier, S.H. Swerdlow, C.M. Schreiner, T.A. Miller, D.W. Pietryga, W.J. Scott Jr., and S.S. Potter. 1991. A functional c-myb gene is required for normal fetal hepatic hematopoiesis. Cell 65: 677-689.

Mutchuchamy, M., L. Pajak, P. Howles, T. Doetschman, and D.F. Wiezorek. 1993. Developmental analysis of tropomyosin gene expression in embryonic stem cells and mouse embryos. Mol. Cell. Biol. 13: 3311-3323.

Nabeshima, Y., K. Hanaoka, M. Hayasaka, E. Esumi, S. Li, I. Nonaka, and Y.-I. Nabeshima. 1993. Myogenin gene disruption results in perinatal lethality because of severe muscle defect. Nature 364: 532-535.

Nishioka, Y. and P. Leder. 1979. The complete sequence of a chromosomal mouse $\alpha$-globin gene reveals elements conserved throughout vertebrate evolution. Cell 18: 875-882.

Orkin, S.H. 1990. Globin gene regulation and switching: Circa
1990. Cell 63: 665-672.

1992. GATA-binding transcription factors in hematopoietic cells. Blood 80: $575-581$.

Pevny, L., M.C. Simon, E. Robertson, W.H. Klein, S.-F. Tsai, V. D'Agati, S.H. Orkin, and F. Costantini. 1991. Erythroid differentiation in chimeric mice blocked by a targeted mutation in the gene for transcription factor GATA-1. Nature 349: 257-260.

Philipsen, S., D. Talbot, P. Fraser, and F. Grosveld. 1990. The $\beta$-globin dominant control region: Hypersensitive site 2 . EMBO I. 9: 2159-2167.

Philipsen, S., S. Pruzina, and F. Grosveld. 1993. The minimal requirements for activity in transgenic mice of hypersensitive site 3 of the $\beta$ globin locus control region. EMBO $/$. 12: $1077-1085$.

Plumb, M., J. Frampton, H. Wainwright, M. Walker, K. Macleod, G. Goodwin, and P. Harrison. 1989. GATAAG: A cis-control region binding an erythroid-specific nuclear factor with a role in globin and non-globin gene expression. Nucleic Acids Res. 17: 73-92.

Risau, W., H. Sariola, H.-G. Zerwes, J. Sasse, P. Ekblom, R. Kemler, and T. Doetschman. 1988. Vasculogenesis and angiogenesis in embryonic-stem cell-derived embryoid bodies. Development 102: 471-478.

Robertson, E.J., A. Bradley, M. Kuehn, and M. Evans. 1986. Germ-line transmission of genes introduced into culture pluripotent cells by retroviral vectors. Nature 323: 445-448.

Romeo, P.-H., M.-H. Prandini, V. Joulin, V. Mignotte, M. Prenant, W. Vainchenker, G. Marguerie, and G. Uzan. 1990. Megakaryocytic and erythrocytic lineages share specific transcription factors. Nature 344: 447-449.

Rudnicki, M.A., T. Braun, S. Hinuma, and R. Jaenisch. 1992. Inactivation of $\mathrm{MyoD}$ in mice leads to up-regulation of the myogenic HLH gene Myf-5 and results in apparantly normal muscle development. Cell 71: 383-390.

Saiki, R.K., S. Scharf, F. Faloona, K.B. Mullis, G.T. Horn, H.A. Erlich, and N. Arnheim. 1985. Enzymatic amplification of $\beta$-globin genomic sequences and restriction site analysis for diagnosis of sickle cell anemia. Science 230: 1350-1354.

Schmitt, R M., E. Bruyns, and H.R. Snodgrass. 1991. Hematopoietic development of embryonic stem cells in vitro: Cytokine and receptor gene expression. Genes \& Dev. 5: 728-740.

Simon, M.C., L. Pevny, M.V. Wiles, G. Keller, F. Costantini, and S.H. Orkin. 1992. Rescue of erythroid development in gene targeted GATA-1 ${ }^{-}$mouse embryonic stem cells. Nature Genet. 1: 92-98.

Sleckman, B.P., A. Peterson, W.K. Jones, J. Foran, J.L. Greenstein, B. Seed, and S.J. Burakoff. 1987. Expression and function of CD4 in a murine T-cell hybridoma. Nature 328: 351353.

Smithies, O., R.G. Gregg, S.S. Boggs, M.A. Kordewski, and R.S. Kucherlapati. 1985. Insertion of DNA sequences into the human chromosomal beta-globin locus by homologous recombination. Nature 317: 230-234.

Sposi, N.M., L.I. Zon, A. Care, M. Valtieri, U. Testa, M. Gabbianelli, G. Mariani, L. Bottero, C. Mather, S.H. Orkin, and C. Peschle. 1992. Cycle-dependent initiation and lineage-dependent abrogation of GATA-1 expression in pure differentiating hematopoietic progenitors. Proc. Natl. Acad. Sci. 89: 6353-6357.

Talbot, D. and F. Grosveld. 1991. The 5' HS 2 of the globin locus control region enhances transcription through the interaction of a multimeric complex binding at two functionally distinct NF-E2 binding sites. EMBO J. 10: 1391-1398.

Talbot, D., S. Philipsen, P. Fraser, and F. Grosveld. 1990. Detailed analysis of the site 3 region of the human $\beta$-globin 
In vitro differentiation of GATA-1- ES cells

dominant control region. EMBO J. 9: 2169-2178.

Todokoro, K., R.J. Watson, H. Higo, H. Amanuma, S. Kuramochi, H. Yanagisawa, and Y. Ikawa. 1988. Down-regulation of c-myb gene expression is a prerequisite for erythropoietininduced erythroid differentiation. Proc. Natl. Acad. Sci. 85: 8900-8904.

Tsai, S.F., D.I. Martin, L.I. Zon, A.D. D'Andrea, G.G. Wong, and S.H. Orkin. 1989. Cloning of cDNA for the major DNAbinding protein of the erythroid lineage through expression in mammalian cells. Nature 339: 446-51.

Wang, R., R. Clark, and V.L. Bautch. 1992. Embryonic stem cell-derived cystic embryoid bodies form vascular channels: An in vitro model of blood vessel development. Development 114: 303-316.

Watt, P., P. Lamb, L. Squire, and N.J. Proudfoot. 1990. A factor binding GATAAG confers tissue specificity on the promoter of the human $\zeta$-globin gene. Nucleic Acids Res. 18: 13391350.

White, E. 1993. Death-defying acts: A meeting review on apoptosis. Genes \& Dev. 7: 2277-2284.

Whitelaw, E., S.-F. Tsai, P. Hogben, and S.H. Orkin. 1990. Regulated expression of globin chains and the erythroid transcription factor (GF-1/NF-E1/Eryf 1) during erythropoiesis in the developing mouse. Mol. Cell. Biol. 10: 6596-6606.

Wiles, M.V. and G. Keller. 1991. Multiple hematopoietic lineages develop from embryonic stem (ES) cells in culture. Development 111: 259-267.

Wilson, D.B., D.M. Dorfman, and S.H. Orkin. 1990. A non-erythroid GATA-binding protein is required for function of the human preproendothelin-1 promoter in endothelial cells. Mol. Cell. Biol. 10: 4854-4862.

Wood, W.G. 1982. Erythropoiesis and haemoglobin production during development. In Biochemical development of the fetus and neonate (ed. C.T. Jones), pp. 127-162. Elsevier Biomedical Press, New York.

Yamamoto, M., L.J. Ko, M.W. Leonard, H. Beug, S.H. Orkin, and J.D. Engel. 1990. Activity and tissue-specific expression of the transcription factor NF-El multigene family. Genes \& Dev. 4: 1650-1662.

Zon, L.I., H. Youssoufian, C. Mather, H.F. Lodish, and S.H. Orkin. 1991a. Activation of the erythropoietin receptor promoter by transcription factor GATA-1. Proc. Natl. Acad. Sci. 88: 10638-10641.

Zon, L.I., C. Mather, S. Burgess, M.E. Bolce, R.M. Harland, and S.H. Orkin. 1991b. Expression of GATA-binding proteins during embryonic development in Xenopus laevis. Proc. Natl. Acad. Sci. 88: 10642-10646. 


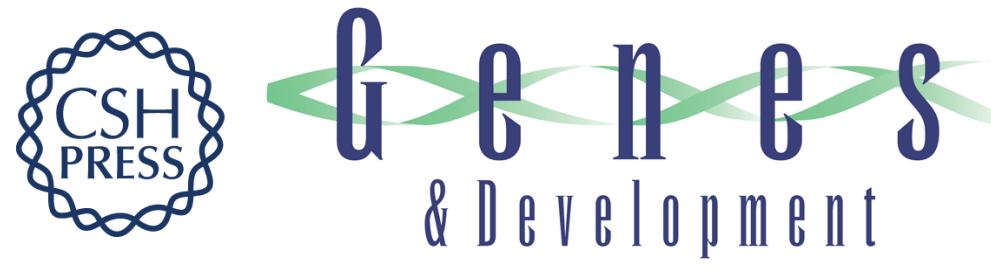

\section{Novel insights into erythroid development revealed through in vitro differentiation of GATA-1 embryonic stem cells.}

M J Weiss, G Keller and S H Orkin

Genes Dev. 1994, 8:

Access the most recent version at doi:10.1101/gad.8.10.1184

References This article cites 82 articles, 42 of which can be accessed free at:

http://genesdev.cshlp.org/content/8/10/1184.full.html\#ref-list-1

License

Email Alerting

Service

Receive free email alerts when new articles cite this article - sign up in the box at the top right corner of the article or click here.

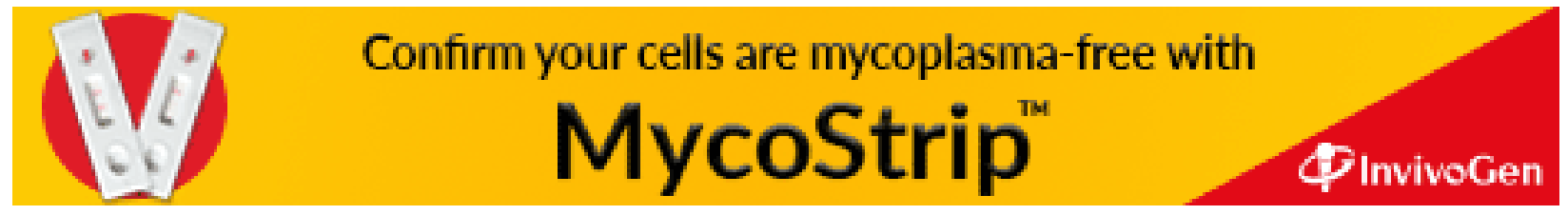

